\title{
The Waterloo longitudinal project: correlates and consequences of social withdrawal in childhood
}

\author{
KENNETH RUBIN \\ LILLY BOTH \\ MARGARET WILKINSON \\ University of Waterloo

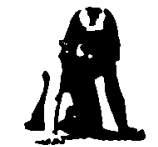 \\ Abstract
}

The focus of this paper is social withdrawal in childhood. We begin with a brief description of two proposed models wchich trace the developmental origins of social withdrawal and isolation. We then present data from the Waterloo Longitudinal Project and discuss the identification, stability, correlates and consequences of social withdrawal in the childhood years. From these data, we conclude that social withdrawal is relatively stable in the early school years, and that it is associated with loneliness, depression and negative self-perceptions of competence in later childhood.

Keywords: Social Withdrawal, Isolation, Rejection, Loneliness, Depression.

\section{El proyecto Longitudinal Waterloo: Rasgos asociados y consecuencias del retraimiento social en la infancia}

\section{Resumen}

Este artículo se refiere al retraimiento social durante la infancia. Comenzamos con una breve descripción de dos modelos propuestos para localizar los origenes evolutivos del retraimiento $y$ del aislamiento social. A continuación presentamos los datos del Proyecto Longitudinal Waterloo y comentamos la identificación, estabilidad, correlaciones y consecuencias del retraimiento social durante la infancia. Con estos datos concluimos que el retraimiento social es relativamente estable durante los primeros años de escolarización y que está asociado con la soledad, la depresión y la percepción personal negativa en los últimos años de la infancia.

Palabras clave: Retraimiento social, Aislamiento, Rechazo, Soledad, Depresión.

Acknowledgements: The research describe in this manuscript was supported by grants from The Ontario Mental Health Foundation, The Ontario Ministry of Community and Social Services, the Social Sciences and Humanities Research Council of Canada, and Health and Welfare Canada. Preparation of this manuscript was aided by a Killam Research Fellowship to author Rubin and a Social Sciences and Humanities Research Council of Canada Doctoral Fellowship to author Wilkinson. Correspondence should be addressed to Kenneth $\mathrm{H}$. Rubin, Department of Psychology, University of Waterloo, Waterloo, Ontario, N2L3G1.

Author Address: K. Rubin, Department of Psychology, University of Waterloo, Waterloo, Ontario, N2L3G1.

Paper received: February, 1989. Revision received: November, 1989. Accepted: December, 1989. 
The past two decades have witnessed an increase in research concerning children's peer relationships. Underlying much of this work, including our own, lies a growing conviction that children who do not enjoy normal social experiences may be "at risk" for later socioemotional difficulties (Parker \& Asher, 1987). Why such children are at risk has not been well addressed; by and large, the literature on the links between qualitative and quantitative aspects of children's peer realtionship and the causes and "outcomes» of these impoverished relationships has been a theoretical and generaly devoid of any meaningful developmental persepctive. In the present paper we present briefly two models of the origins and developmental course of social withdrawal and isolation in childhood that have been developed from our work in the Waterloo Longitudinal Project.

\section{Theories Concerning the Importance of Children's Peer Relationships}

The benefits of early peer relationships for promoting development and personal adjustment have been asserted by theorists representing several perspectives. For example, Piaget (1926), in his earliest writings, contended that it was through peer interaction, particularly episodes of conflict and the opportunities for negotiation which they create, that children come to develop the capacity for sensitive perspective-taking in interpersonal relationships. Relationships with adults were characterized as being adult dominated; therefore, it was within the more balanced and egalitarian relations with peers that many social-cognitive developments were thought to occur.

Like Piaget, another early theorist, Mead (1934) emphasized the importance of the development of perspective-taking through peer interaction. Play and peer interaction, especially as it occurs in rule-governed games, was proposed in Mead's theory of symbolic interactionism, to gradually help develop the child's ability to self-reflect. While engaged in organized activities, children were thought to learn to consider and coordinate the perspectives of multiple others with respect to the self. Eventually an organized sense of self was hypothesized to develop from the integrated persepctives of ones's social group. Thus, according to Mead, social interaction was critical for the development of perspective-taking and the selfsystem (see Harter, 1983 for a review).

Learning and social learning theory is yet another stimulus of current research on children's peer relationsships and social skills. It was originally suggested, and it is now known, that children learn about their social worlds, and how to behave within them, through direct peer tutelage as well as by observing each other. More recently, the classic personality theory of Sullivan (1953) has served as a guide for the current research concerning children's peer relationships and social skills. Sullivan suggested that the foundations of mutual respect, cooperation, and interpersonal sensitivity were a result of chidren's peer, and especially, of friendship relationships.

Taken together, these early theories and the data supportive of them (see Hartup, 1983 for a recent review) have led psychologists to conclude that peer interaction is an important force in the development of normal social relationships and social skills. Thus, the child who does not have ade- 
quate peer relationship experiences may indeed be at risk for later maladjustament. Clinical sources reinforce such a conclusion. For example, consistent with this notion of risk, a number of researchers have demonstrated that the experience of negative peer relationships in childhood, particularly those caused by aggression, is predictive of psychopathology, school dropout, and delinquency in adolescence and adulthood (see Parker \& Asher, 1987 for a review). Clinical psychologists have, however, consistently distinguished between aggression and withdrawal in childhood and have suggested that both have important prognostic value (e.g., Ledingham, 1981); yet, while there have been numerous longitudinal investigations of the course of childhood aggression (e.g., Huesmann, Eron, Lefkowitz, \& Walder, 1984) there have been few follow-forward investigations concerning the prognoses for children who have insufficient peer relationships (that is, those who are socially withdrawn). This lack of attention to social withdrawal exists despite the fact that numerous psychological disturbances in childhood (e.g., shyness disorder, adjustment disorder with withdrawal; and introverted disorder, DSM III-R) implicate peer relationships insufficiencies as indices of psychopathology.

A case can be made then, for studying children who deviate from the norm in their peer interaction experiences. Clearly, whether peer relationships are a driving force in development or whether they merely reflect general psychological adjustment, children who have poor or nonexistent relationships with peers are likely at risk for some form of psychological difficulty. Despite the logic of this conclusion, however, the risk factors of the two major forms of peer disturbance which have been studied to date -aggression and social withdrawal - differ considerably in status. Consistently, reviews of research linking early peer disturbances with later outcomes report strong evidence that aggressiveness toward peers in childhood is predictive of socio-emotional disturbance in adolescence and adulthood, and a dearth of supportive evidence relating social withdrawal to such outcomes (Parker \& Asher, 1987).

\section{Developmental Pathways to and from Social Isolation and Peer Rejection}

Recently we have hypothesized different outcomes of peer isolation and rejection resulting from at least two distinct developmental pathways $(\mathrm{Ru}-$ bin, Hymel, Mills, \& Rose-Krasnor, in press). In this model we link rejection and isolation to the display of early hostility and aggressiveness toward peers as well as to passive-anxious behaviors of children. Briefly, the pathway to childhood aggression may begin at birth with a temperamentally dfficult infant who receives less than optimal parenting practices and subsequently develops an insecure attachment relationship with his/her primary caregiver. Recently, researchers have shown that childhood aggression toward peers can be predicted from insecure, avoidant parental attachment in infancy (Egeland \& Sroufe, 1981; Londerville y Main, 1981; Sroufe, 1983; Troy \& Sroufe, 1987). Whether aggression is the result of poor primary attachments or stems from other causes, it is nevertheless a highly salient, determining cause of peer rejection (Coie \& Kupersmidt, 1983; Rubin \& Daniels-Beirness, 1983). Thus, once identified as aggressive and once 
rejected by peers, the proactively aggressive child may soon become isolated by his or her community of age-mates (e.g., Dodge, 1983). Thus, in the first developmental pathway, social isolation or social solitude may be the involuntary product of aggression and rejection.

Our second pathway suggests that wariness may be a dispositional trait (Kagan, Reznick, \& Snidman, 1987) and that when initially wary babies are responded to unresponsively and insentively by their parents anxiousinsecure attachments of an ambivalent nature may result. (Belsky y Rovine, 1987). It is proposed further that when these anxious-insecure children reach preschool age, they will tend to avoid unfamilar peer groups when they first enter school. Reticence to explore novel settings and shy withdrawn behavior reduces opportunities for social interative play behavior and the establishment of close peer relationships. Thus, opportunities to learn the social and cognitive behaviors supposedly encouraged by these relationships and interactive play behaviors are reduced. The failure to develop social skills may result in increased feelings of anxiety and isolation from the peer group. However, unlike the children described in the first pathway, social anxiety leading to withdrawal emanates first from the child (that is, she or he isolates her/himself from the peer group) and this behavior, once it is recognized as deviant, (by mid to-late childhood, Younger \& Boyko, in press; Younger, Schwartzman, \& Ledingham, 1986), results in peer rejection.

The developmental pathways just described suggest that the sources of behavioral isolation and social rejection can vary. It is likely that the outcomes for children who follow these pathways differ as well. For example, it has been well documented that early assessments of hostility and aggression in childhood are predictive of juvenile delinquency and adult criminality (e.g., Olweus, 1979; Parker \& Asher, 1987); as such it would appear that children who are rejected and isolated by the peer group because of their aggressive behaviors, may be at risk for the development of externalizing disorders (Achenbach \& Edelbrock, 1982).

We would expect a different outcome for children following the second pathway. Conceptually, one might predict that when these passive-witndrawn children are able, cognitively, to make social comparisons, they will come to realize that they are failing in their social worlds, and they may become distressed and fall into despair. One might predict, therefore, that these highly sensitive, insecure, withdrawn children will be at risk for problems of an internalizing nature (e.g., anxiety and depressive disorders).

Until very recently, there has been a dearth of data supporting the view that socially withdrawn children are at risk for negative outcomes (Quay \& La Greca, 1986; Robins, 1972). However, our own thoughts (and data) suggest that this conclusion concerning the non-risk status of socially withdrawn children is based on unsound reasoning and poor methodology. For example, of the studies in which socially withdrawn children have been followed forward to adolescence or adulthood, four (Janes, Hesselbrock, Myers, \& Penniman, 1979: Michael, Morris, \& Soroker, 1957; Morris, Soroker, \& Burruss, 1954; Robins, 1966) provide no support for a link between early withdrawal and a negative outcome of adolescent psychopathology, and two (Janes \& Hesselbrock, 1978; John, Mednick, \& Schulsinger, 1982) provide support for such a relationship in girls only. However, 
important methodological flaws, characteristic of the peer relations risk literature in general, are shared by all of these studies. First, clinic or highrisk populations were used in all the studies. Such samples tend to result in an attenuated range of observed behavior and thus an underestimate of the correlation with later outcomes. Second, all studies relied on teacher assessments of withdrawal; the validity of these measures is largely unknown (Hymel \& Rubin, 1985). Third, risk associated with social withdrawal has typically been assessed for the wrong type of outcome (delinquent activity). We would argue that more probable maladaptive outcomes of subdued and reticent childhood behavior may be those of an «internalizing" nature, such as social anxiety and depression (Rubin \& Lollis, 1988).

In the Waterloo Longitudinal Project we examined the risk status of childhood social withdrawal, unhampered by these methodological drawbacks. Unfortunately, we have not been able to examine, in our data, the infant-toddler precursors of social withdrawal as described above in the Pathways. At this time, however, our data do allow close examination of the correlates and consequences of social withdrawal in the age period 5-11 years.

\section{THE WATERLOO LONGITUDINAL PROJECT (WLP)}

The Waterloo Longitudinal Project (WLP) was initiated in 1980 to investigate the implications of early social withdrawal for later development. The project was guided by the growing body of evidence that suggested peers played a significat role in normal growth and development of social skills. Specifically we were interested in determining whether socially withdrawn children, who are deprived of the opportunities to interact with their peers, may be «at risk» for later difficulties.

The longitudinal project has followed two cohorts of children from five to eleven years of age and has resulted in a substantial longitudinal data base consisting, presently, of information regarding the concurrent and predictive correlates of social withdrawal or isolation in childhood. In the remainder of this paper, we will focus on the identification, stability and correlates of social withdrawal in early, middle and late childhood.

\section{Identification of socially withdrawn children}

The original cohort of children in the WLP was comprised of approximately 110 kindergarteners, to which we added another 70 kindergarteners in a second cohort. These 180 children attended regular public schools in a Canadian community of abour 250,000 people. In a follow-up study in the second grade, we had access to 105 children of the original group. In grade 4, 49 members of the first cohort remained; by grade 5, this number was reduced to only 46 . In each year of the project, however, we added new children to the sample. Thus, in grade 4 , the actual number of participants was 81 ( 58 for whom we had data in grade 2 from both cohorts) and in grade 5, the total number of participants was 77 (51 for whom data were available in grade 2). The following summary will focus primarily on the data from kindergarten through grade 5 for cohort 1 , and kindergarten through grade 2 for both cohorts combined. 
To measure sociability and withdrawal, children in kindergarten, grades 2 and 4 were observed in free play with their peers. In kindergarten, each child was observed in his or her classroom following procedures outlined in detail elsewhere (e.g., Rubin, 1982a; Rubin \& Mills, 1988). Briefly, each child was observed for six 10-sec time sampled intervals each day over a 30-day period, bringing the total number of observations to 30 mins per child. In grades 2 and 4, however, there were no opportunities to observe free play within the regular daily curriculum and thus, each child was invited to play with three other same-age, same-sex peers for four 15-minute free play sessions in a laboratory playroom. In each of these sessions, the focal child's playmates differed in order to allow interaction to occur with 12 different playmates. Observations were made from behind one-way mirrors for 42 10-sec time intervals for each of the four sessions (or a total of 28 mins per child).

The behaviors were coded on a checklist that included the social participation categories of solitary, parallel and group activities. Nested within these categories were the cognitive play categories of functional-sensorimotor, exploratory, constructive, dramatic and games-with-rules behaviors. Other categories noted were unoccupied, onlooker and transition behaviors, as well as aggresion, rough-and-tumble play, and conversations with peers. The affective quality of each interaction was coded as positive, neutral or negative. Afther the play behavior was recorded, the observers noted the names of the focal child's play partners and who it was that initiated the activity. An example of this coding frame is provided in Figure 1.

In grades 2, 3, 4 and 5 children were administered The Revised Class Play (Masten, Morison, \& Pelligrini, 1985) which required children to nominate up to three classmates who would best fit each of 30 behavioral descriptors. The nominations for each child were standardized within sex and class and were used to compute three factor scores as outlined by Masten et al. (1985): sociability-leadership, aggression-disruption, and sensitivityisolation (CPISO).

A closer examination of the items that comprise the CPISO factor revealed, however, that this factor is actually comprised of two sub-clusters of items. Four of the items appear to describe passive-anxious withdrawal («someone who would rather play alone than with others», «someone whose feelings get hurt easily», «someone who is very shy», and «someone who is usually sad") which profiles a child who is isolated from the peer group. The remaining three items appear to describe a child who is isolated by the peer group, that is, these items are indicative of peer rejection («a person who can't get others to listen", «someone who has trouble making friends", and «someone who is often left out»). Indeed, the first two items in this latter cluster actually load significatly on both the aggression-disruption and sensitivity-isolation factors (Masten et al., 1985). Because peer rejection is correlated with aggressive and disruptive behaviors (Coie $\& \mathrm{Ku}$ persmidt, 1983; Dodge, 1983) as well as with social withdrawal (French, 1988; Rubin, Hymel, Lo Mare \& Rowden, 1989), it appeared necessary to tease apart the Revised Class Play items that reflected peer rejection from the items that reflected passive, anxious withdrawal from peers. Thus, the research presented below is based only on the passive-anxious withdrawn items on the CPISO factor score. We refer to this cluster as CPISOW. 
FIGURE 1

\begin{tabular}{|c|c|c|c|c|c|c|}
\hline \multicolumn{7}{|c|}{ 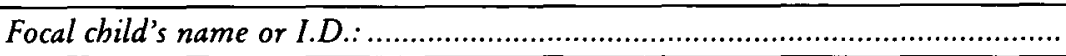 } \\
\hline & \multicolumn{6}{|c|}{ Time Sample } \\
\hline & 1 & 2 & 3 & 4 & 5 & 6 \\
\hline $\begin{array}{l}\text { Unoccupied } \\
\text { Onlooker } \\
\text { Conversations }(+,-, 0) \\
\text { Rough \& Tumble } \\
\text { Aggression } \\
\text { Transitional } \\
\text { Solitary: }\end{array}$ & & - & & & & \\
\hline $\begin{array}{l}\text { Functional } \\
\text { Exploratory } \\
\text { Constructive } \\
\text { Dramatic } \\
\text { Games }\end{array}$ & & & & & & \\
\hline Parallel: & & & & & & \\
\hline $\begin{array}{l}\text { Functional } \\
\text { Exploratory } \\
\text { Construtive } \\
\text { Dramatic } \\
\text { Games }\end{array}$ & & & & & & \\
\hline Group: (Code affect as,,+- 0 ) & & & & & & \\
\hline $\begin{array}{l}\text { Functional } \\
\text { Exploratory } \\
\text { Constructive } \\
\text { Dramatic } \\
\text { Games }\end{array}$ & & . & & & & \\
\hline $\begin{array}{l}\text { Direct contact } \\
\text { W-in arm's length (code adult } \\
\text { or child) }\end{array}$ & & & & & & \\
\hline $\begin{array}{l}\text { Oriented to } \\
\text { Not oriented to }\end{array}$ & & & & & & \\
\hline Beyond arms length & & & & & & \\
\hline $\begin{array}{l}\text { Oriented to } \\
\text { Not oriented to }\end{array}$ & & & & & & \\
\hline
\end{tabular}

Play Observation Scale

\section{The Stability of Social Withdrawal}

\section{Stability of extreme group identification}

The stability of withdrawal was computed in two ways. First, as in Rubin (1982a), an extreme-group targetting procedure was used to identify extremely withdrawn children on the basis of the observational data. Each child received a score based on the frequency with which s/he was obser- 
ved to engage in social behavior (all forms of group play + conversations with peers = SOCPLAY), and non-social behavior (unoccupied + onlooker + all forms of solitary play $=I S O P L A Y$ ). Socially withdrawn children were identified as those whose ISOPLAY scores were 1 sd above the $M$ for their age group, and whose SOCPLAY scores were below their agegroup $M \mathrm{~s}$. (In kindergarten, children had to fit these criteria as well as being $10 \%$ above their class means on ISOPLAY in order to be identified as extremely withdrawn. This latter criterion was added to control for variations in classroom setting). With this procedure, 26 Isolates were identified (18 in cohort 1 and 8 in cohort 2 ) and comprised $14.44 \%$ of the total sample.

In grade 2, 153 children were observed, of whom 105 had been observed previously in kindergarten. From this group of 153 children, 16 Isolates were identified (or $10.46 \%$ of the total sample); for 12 of these children, data were available in kindergarten. Eight of these 12 children (or $66.7 \%$ ) had been earlier identified as extremely withdrawn. Taken together, these data suggested to us that extreme social withdrawal is quite stable in early childhood.

The revised Class Play was employed as a second targetting procedure to identify extremely withdrawn children. In this case, stability data were available only for the children in Cohort 1 . Isolates were identified as those children whose CPISOW scores were one $S D$ above the age group $M$ and whose sociability-leadership (CPSOC) factor scores were below the $M$. This procedure identified 16 socially withdrawn children in Grade 2 (or $18.18 \%$ of the sample), 18 children in Grade 4 (22.22\% of the sample), and 18 children in Grade $5(23.37 \%)$.

Of the 13 social isolates in Grade 4 for whom data were available in Grade 2, nine had been likewise identified (or $69.23 \%$ stability). Of the 11 social isolates in Grade 5 for whom data were available in Grade 2, six had been so identified (i.e., $54.54 \%$ stability), and of the 15 Grade 5 isolates for whom data were available in at least one of the previous years, 10 had been identified earlier as withdrawn (or $66.67 \%$ stability).

\section{Correlational stability}

The stability of social withdrawal has also been examined by conducting a series of grade-by-grade correlational analyses. Observational indices of withdrawal were available in kindergarten and Grade 2 for both cohorts, and in Grade 4 for Cohort 1. It is important to reiterate, however, that observational settings differed considerably for the kindergarten versus the school age samples (i.e., free play periods versus laboratory free play quartets, respectively). The most direct test of stability, then, was examination of the two year stability correlations (one-tailed) obtained across the second to fourth grade period, available for a longitudinal sample of 58 children. Some modest degree of stability was observed across the two-year period for ISOPLAY, $r(56)=.37, p<.002$.

Although observational data obtained in kindergarten were not directly comparable to those obtained in Grades 2 and 4 due to methodological variations, the relations between the index of withdrawal was, nonetheless, of interest. Some degree of stability was observed across the kindergarten 
to Grade 2 period for overall social withdrawal, $r(105)=.25, p<.01$; however, the kindergarten to Grade 4 correlation was non-significant. Thus, these data suggest some degree of stability for observed social withdrawal, at least across the two-year period from Grade 2 to Grade 4 and despite methodological variations.

When peer assessments of withdrawal were used in the analyses, somewhat higher stability correlations were obtained. Grade-by-grade correlations for peer assessed isolation (i.e., CPISOW) were Grade 2 to 4, $r(55)=.53, p<.001$; Grade 2 to $5, r(49)=.38, p<.001$; and Grade 4 to 5 , $r(67)=.40, p<.001$.

In summary, it appears as if social withdrawal in early childhood is a relatively stable phenomenon. The relative stability of social withdrawal bolsters the evidence extant documenting the longitudinal continuity of social withdrawal (Bronson, 1966; Feldman \& Cohen, 1987; Kagan \& Moss, 1962; Moskowitz, Schwartzma, \& Ledingham, 1985; Olweus, 1981). Although these sudies vary considerably in time spans covered, developmental periods involved, and measures employed, they show quite consistently that social withdrawal tends to persist across time. Given these data, the next issue to address, then, is whether there are "risks" involved in being socially withdrawn. This is the issue we address below.

\section{Correlates of Withdrawal in Early Childhood}

What do socially withdrawn children «look like» psychologically at different points in childhood? First, we describe preschool and kindergarten children. The preschoolers $(n=126)$ studied were participants in the original cross-sectional investigation that set the stage for the WLP (Rubin, 1982a, b).

The data indicated that extremely withdrawn children did not appear to evidence major developmental difficulties. They played in less cognitively mature ways than their more sociable counterparts; furthermore, they spent more time talking to inanimate objects than their sociable peers. However, teachers did not regard withdrawn children as problematic on the basis of behavior ratings. Moreover, their peers did not dislike or reject then (Rubin, 1982a). To some extent then, these particular data portray young «isolates» as somewhat immature, but not at seeming risk for any predictable negative outcome.

A very different picture emerged, however, when these socially withdrawn four and five year olds were paired with non-withidrawn, «average» children of the same sex and age, in dyadic free play. First, withdrawn children directed fewer requests to their play partners (e.g., "Can yor give me that crayon?»; "Come over here!»). As such, they may be characterized as less sociable and as taking less social initiative than their non-withdrawn counterparts (Rubin \& Borwick, 1984; Rubin \& Krasnor, 1986). Second, when young, withdrawn children did issue requests, they were likely to be of a «low cost" nature; that is, they were more likely to try to get the attention of their playmates (e.g., "Look at this car.») than to try to gain access to objects in their partner's possession, to stop their partner's activity, or to get their partner to join them in play (Rubin \& Borwick, 1984; Rubin \& Krasnor, 1986). These latter goals would require much more expen- 
diture of energy by the play partner than the goal of «gain partner's attention». These data suggest that the withdrawn child is less socially assertive than her or his more sociable age-mates.

This, despite issuing more requets of a low cost nature, it was nevertheless the case that withdrawn children's requests resulted in higher frequencies of rebuff and ignoring by their playmates (Rubin \& Borwick, 1984; Rubin \& Krasnor, 1986). These data indicated that within these dyadic groupings, withdrawn children did experience rejection in the form of non-compliance and non-responsiveness.

Finally, when we interviewed preschoolers and kindergarteners and asked them how they would go about acquiring objects or initiating social activities with peers, we found that withdrawn youngsters were more likely to suggest that they would get and adult to help them solve their interpersonal problems. These responses to hypothetical dilemmas may be contrasted with those of aggressive children who were more likely to suggest that they would hit, threaten, or bribe their social «targets» (Rubin, 1982a; Rubin, Bream, \& Rose-Krasnor, in press; Rubin, Daniels-Beirness, \& Bream, 1984; Rubin \& Krasnor, 1986).

In summary, preschool and kindergarten withdrawn children were neither perceived as problematic by teachers nor disliked by peers. The play of these children, however, was relatively immature and observational indices of social competence painted a picture of nice, quiet, highly compliant, and submissive children who experienced a higher than average degree of social failure. It is important, however, that these data not be taken lightly, specially when considered in relation to recent research concerning the early development of internalizing disorders in childhood. Thus, in addition to our reports that withdrawn children are more immature and socially deferent and submissive, other researchers have found that they also appear to experience greater felt insecurity in their attachment relationships (LaFrenière \& Provost, 1988) and that they experience more depression (Erickson, Bacon, \& Egeland, 1987) than their more sociable age-mates. As the reader will note, these internalizing concomitants of social withdrawal appear continuous throughout the years of childhood.

\section{Correlates of Social Withdrawal in Middle Childhood}

As aforementioned, social withdrawal is a relatively stable phenomenon; two-thirds of kindergarten isolates were likewise identified in Grade 2. However, the correlates of social withdrawal in the mid-years of childhood appear somewhat stronger and more severe than those of early childhood.

At this age (approximately seven years), extremely withdrawn children were not rated as unpopular by their peers (Rubin, 1985). They were viewed by peers, however, as passive, fearful and withdrawn (Rubin \& Cohen, 1986; Rubin \& Mills, 1988). Thus, although not disliked sociometrically, withdrawn children were perceived accurately by their peers.

In the second grade, we also asked the children how they would resolve a number of interpersonal problems such as initiating a friendship, obtaining a desired object, and seeking help. In general, extremely withdrawn children were as able as their more sociable counterparts to produce nu- 
merous and competent strategies (Rubin \& Krasnor, 1986). When we observed the children in free-play dyads and examined social dominance attempts, however, we discovered that withdrawn children were less likely than their more sociable counterparts to play managerial or teacher roles; when they did try to play dominant roles they were more often rebuffed. In this case, just as we found in early childhood, observations of rebuff occurring in dyads indicated that withdraw children did experience a form of rejection by their play partners.

Additionally, in the second grade, we administered Harter's (1982) Perceived Self Competence Scale to the children; given that the withdrawn children did experience a higher than average rate of social rebuff, it is not surprising that significant associations were found between both observed and peer assessed social withdrawal and negative self-perceptions of social competence and general self-worth (Rubin, 1985; Rubin \& Mills, 1988).

Finally, in grade 2, the children's teachers were requested to complete the Child Behavior Questionnaire, an index of internalizing and externalizing disorders (Rubin, Moller, \& Emptage, 1987). We found that the teachers rated as withdrawn, anxious, and fearful those children observed and rated by peers as most socially withdrawn (Moller \& Rubin, 1988).

Taken together, the kindergarten and second grade data from the WLP as well as those data from other recent reports suggest that social withdrawal may reflect internalizing difficulties such as anxiety, negative self-perceptions, felt insecurity (LaFrenière \& Provost, 1988; Erickson et al., 1987) and possibly depression (Altmann \& Gotlib, 1988).

\section{Correlates of Social Withdrawal in Later Childhood}

Recently, we have begun to analyze data concerning the correlates of social withdrawal in the later years of childhood, that is when children are ten and eleven years of age. Our observational and peer assessments of social withdrawal have been found to correlate significantly and negatively with observed and peer assessed sociability and with negative self-perceptions of social competence. Moreover, positive associations are evidenced with indices of loneliness, depression, and peer rejection (Rubin, Hymel, LeMare, \& Rowden, 1989; Rubin \& Mills, 1988). These latter data provide some support for our contention that with age, social withdrawal becomes increasingly salient and negatively evaluated by the peer group (Rubin $\&$ Mills, 1988). In addition, withdrawal continues to be a reflection of internalizing difficulties in the fourth and fifth grades.

The above described findings bring us to the end of the data completion phase for the first cohort of the WLP. Given the results of our analyses, we must disagree with previous assertions that social withdrawal is not a risk factor in child development. It is important, however, to strengthen our argument by examining the predictability of internalizing difficulties in later childhood from the frequent experience of social solitude in early childhood. We do so in the following section.

\section{The Risk Factors Associated With Childhood Withdrawal}

A major purpose of the WLP has been to investigate whether social withdrawal in early and mid-childhood predicts negative psychological out- 
comes in late childhood. Typically psychosis or criminal activity are assumed to be the most likely outcomes of social withdrawal, in studies suggesting a risk of socioemotional difficulties (Ensminger, Kellam, \& Rubin, 1983; Robins, 1966). In contrast, we have argued that social withdrawal suggest a prognosis of internalizing problems, anxiety, and feelings of loneliness and depression. A relatively small number of children from Cohort 1 remained continuously in the sample from kindergarten to grade five; thus for our predictive anlyses, we have not been able to make large scale comparisons between extremely withdrawn and other children. Instead, we have used our earlier observations and peer assessments of nonsocial play as continuous variables to predict later "outcomes» in a series of statistical analyses. The outcome variables were derived from our developmental model in which we suggested that internalizing problems should be the consequence or early insecurity/anxiety and social isolation; consequently, we chose measures of depression, anxiety, loneliness and negative self-worth in grades 4 and 5 as logical outcomes. The predictor variables we chose were those that best demonstrated for us, the construct of insecurity/anxiety/social isolation in kindergarten and grade 2.

It is important to note that from the outset we distinguished between different forms of social withdrawal for these analyses. Our kindergarten and grade 2 data indicated that aproximately $80 \%$ of all solitary activity consisted of quiescent, constructive or exploratory behavior. Quiescent solitary behavior was labelled ISOPASS or passive isolation. The second form of solitary activity was that which included solitary-pretense and solitarysensorimotor activities, two forms of immature and rambunctious solitary play. We labelled this type of behavior $I S O A C T$, or active isolation. In grade 2, ISOPASS was significantly correlated with peer nominations of social isolation and sensitivity and not with any derived indices of hostility or aggression ISOACT, on the other hand was not related with teacher and peer assessments of withdrawal of fearfulness; rather it related significantly with teacher and/or peer derived indices of aggression (see Rubin \& Mills, 1988, for an extended description of these different "faces" of social withdrawal).

Given this background information, we conducted a series of analyses to predict grades 4 and 5 assessments of depression, loneliness, general selfworth, and anxiety from kindergarten and grade 2 measures of ISOPASS and ISOACT. Our analyses revealed that the frequency with which children were observed to engage in passive-withdrawn behavior in kindergarten during free-play was significantly and positively associated with lonelines in grade 4 and with self-reported depression in grade 5. Passive withdrawal in kindergarten was negatively associated with measures of general self-worth in both grades 4 and 5 . Active forms of isolation were non-significantly associated with all "outcome» measures in grades 4 and 5 (Rubin et al., in press; Rubin \& Mills, 1988).

Passive-withdrawal in grade 2 correlated significantly with loneliness in grade 4 and with depression and teacher rated anxiety in grade 5 . Once again, active isolation was not-significantly linked with any of the grades 4 and 5 "outcomes" (Rubin et al., in press; Rubin \& Mills, 1988).

Two additional findings are worthy of note. First, we have never assumed, in our longitudinal research, that social withdrawal, in and of itself, 
is a cause of malevolent outcome. Instead, we have suggested, from the outset, that withdrawal is a marker, reflection, or symptom of underlying psychological problems such as insecurity, negative self-appraisals, and anxiety from early in childhood. Accordingly, in a series of regression analyses, we have demonstrated that the constellation of early passive withdrawal, anxiety and negative self-perceptions of social competence in Grade 2 is significantly associated with measures of depression, loneliness, and anxiety, but not with indices of aggression and hostility in Grade 5 (Rubin \& Hymel, 1987; Rubin \& Mills, 1988). Indeed, perceived social competence in grade 2 was a stronger predictive correlate of grade 5 lonelines $(4[48]=-.65, p<.001)$ and depression $(r[39]=-.53, p<.001)$ than was passive withdrawal. Thus, it appears as if the clearest predictors of internalizing problems in late childhood are observed social withdrawal and variables that are concurrently associated with a lack of social interaction. As such, one conclusion that may be drawn from the WLP is that social withdrawal is a risk factor because (a) it reflects contemporaneous problems concerning the child's self-regard and affect (Rubin, 1985; Rubin \& Mills, 1988 ) and (b) in concert with these underlying difficulties it predicts subsequent problems of an internalizing nature.

Second, and perhaps of equal importance to the above reported predictive results was our finding that grade 2 measures of aggression were significantly predictive of peer and teacher derived «outcomes» of aggression and hostility in grade 5; yet, they were not predictive of any outcome of an internalizing nature (Rubin \& Hymel, 1987; Rubin \& Mills, 1988). These data are thus in keeping with earlier work on the stability. of aggression and are consistent with the finding that aggression in childhood predicts externalizing and not internalizing difficulties in adolescence and early adulthood (e.g., Huesmann, Eron, Lefkowitz, \& Walder, 1984). In addition, passive withdrawal as observed in kindergarten and grade 2 was not found to be predictively associated with peer or teacher derived indices of externalizing difficulties in grades 4 and 5 . Typically, studies of the risk status of social withdrawal assume psychosis or criminal activity to be its most likely outcomes (Ensminger, Kellan, \& Rubin, 1983; Robins, 1966); as aforementioned, these studies rarely, if ever, report significant relations between withdrawal and these outcomes. Our own data support this contention, but add a significant proviso. If one looks for the wrong outcomes, one finds nothing of consequence. If one arrives with a conceptually sound developmental perspective, support can be found for a connection between early social withdrawal and later psychological difficulties.

\section{THE WATERLOO LONGITUDINAL PROJECT: SOME CONCLUDING REMARKS}

In summary, we began the WLP in an effort to make some sense of the controversies and discrepancies reported on the phenomenon of childhood social withdrawal. Many clinicians have believed that social withdrawal does not represent a risk factor for abnormal development (e.g., Ensminger et al., 1983; Kohlberg, LaCrosse and Rickets, 1972; Robins, 1966). On the other hand, their exist a multitude of intervention programs designed 
to prevent or ameliorate the supposed negative consequences of social withdrawal or to prevent or ameliorate the supposed negative problems said to be reflected by the consistent display of non-social, solitary activity (see Conger \& Keane, 1981 for a review). Beyond this, there exist developmental theories and data that extoll the significance of peer interaction for nomal child development (Hartup, 1983).

To date, our own longitudinal study of normal, school attending children has demonstrated that social withdrawal (a) is stable; (b) is associated concurrently, from early through late childhood, with measures conceptually reflective of felt insecurity, negative self esteem, dependency, and social deference, and (c) that in addition to negative self-appraisal, social withdrawal is significantly predictive of internalizing difficulties in late childhood. It is extremely important to note, however, that since we sampled a normal school population, our data support a predictive relation between withdrawal and nonclinical depression; this leaves open, for future research, the question of whether passive withdrawal and negative social self-perceptions in early childhood can predict clinical depression in late childhood.

Our research leads us to two major conclusions. First, with development, children may arrive at a given "outcome» in different ways. We have suggested that there are at least two distinct pathways to the outcome of peer rejection and social isolation. Second, we have suggested that the outcome of social isolation, if arrived at by different pathways, will have differential results. Specifically, we argue that although some isolated and rejected children may be at risk for subsequent externalizing difficulties, others may be more at risk for later internalizing problems.

In future research we plan a follow-up study of those children in the first cohort of the WLP as they enter high school in the autumn of 1989. This will allow an examination of how a critical school transition affects children with varying psychological profiles (withdrawn, aggresive, popular, unpopular). We will be able also to test our hypotheses concerning differential outcomes for those who have been isolated by the peer group for earlier aggressive behavior and those who have isolated themselves from peer interaction because of underlying negative self perceptions and social anxieties. Other new research in our lab concerns the determinants of social withdrawal in childhood. In a series of studies, we are examining the infantile predictors of social withdrawal in early childhood. Both dispositional factors (temperament) and relationships factors (security of attachment) are being examined in tandem with parental beliefs and socialization strategies-vis-à-vis their causal associations with the development of social competence and social withdrawal. Our belief that social withdrawal places some children at risk for later social difficulties leads us to encourage further investigation of this conceptually rich and compelling topic in the study of social and emotional development. 


\section{References}

ACHENBACH, T. M., EDELBROCK, C. S. (1981). «Behavioral problems and competencies reported by parents of normal and disturbed children aged four through sixteen». Monographs of the Society for Research in Child Development, 46, (1, Serial No. 188), 1-82.

ALtManN, E. O., GothiB, I. H. (1988). *The social behavior of despressed children: An observational study". Journal of Abnormal Child Psychology, 16, 29-44.

BELSKY, J., RoviNE, M. (1987). "Temperament and attachment security in the strange situation: An empirical rapprochment". Child Development, 58, 787-795.

BRoNSON, W. C. (1966). «Central orientations: A study of behavior organization from childhood to adolescence». Child Development, 37, 125-155.

COIE, J. D., KUPERSMIDT, J. R. (1983). *A behavioral analysis of emerging social status in boys' groups». Child Development, 54, 1400-1416.

CONGER, J. C., KEANE, S. P. (1981). «Social skills intervention in the treatment of isolated or withdrawn children». Psychological Bulletin, 90, 478-495.

DODGE, K. A. (1983). «Behavioral antecedents of peer social status». Child Development, 54 , 1386-1389.

EGELAND, B., SROUFE, L. A. (1981). «Developmental sequelae of maltreatment in infants». In R. Rizley D. Cicchetti (eds.), Developmental perspectives in child maltreatment. San Francisco: Jossey-Bass.

ENSminger, M. C.; Kellam, S. G., RUbiN, B. R. (1983). «School and family origins of delinquency: Comparison by sex». In K. T. Van Dusen and S.A. Mednick (eds.), Prospective studies of crime and delinquency, pp. 73-97. Hingham, MA: Kluwer-Nijhoff Publishing.

ERICKSON, M. F. BACON, M., EGELAND, B. (abril, 1987). Developmental antecedents and concomitants of depressive symptoms in preschool children. Paper presented at the Biennial Meeting of the Society for Research in Child Development.

Feldman, J. F., COHEN, P. (april, 1987). Persistence of emotional and behavioral problems from preschool to preadolescence in a community sample. Paper presented at the Biennial Meeting of The Society for Research in Child Development, Baltimore, Maryland.

FRENCH, D. (1988). «Heterogeneity of peer rejected boys: Aggressive and non-aggressive subtypes". Child Development, 59, 976-985.

HARTER, S. (1982). «The perceived competence scale for children». Child Development, 53, $87-97$.

- (1983). "The self system». In E. M. Hetherington (ed.), Handbook of child psychology: Vol. 4, Socialization, personality, and social development. New York: Wiley.

HaRTuP, W. W. (1983). «Peer relations». In E. M. Hetherington (ed.), Handbook of child psychology: Vol. 4, Socialization, personality, and social development, pp. 103-198. New York: Wiley.

HuesmanN, L. R.; ERon, L. D.; Lefkowitz, M. M., Walder, L. O. (1984). «Stability of aggression over time and generationsw. Developmental Psychology, 20, 1120-1134.

HYMEL, S., RUBIN, K. H. (1985). «Children with peer relationships and social skills problems: Conceptual, methodological, and developmental issues». In G. J. Whitehurst (ed.), $A n$ nuals of child development, Vol. 2, pp. 251-297. Greenwich, CT: JAI Press.

JANES, C. L., HESSELBROCK, V. M. (1978). «Problem children's adult adjustment predicted from teachers' ratings". American Journal of Orthopsychiatry, 48, 300-309.

Janes, C. L.; Hesselbrock, V. M.; Myers, D. G., Penniman, J. H. (1979). «Problem boys in young adulthood: Teachers' rating and twelve-year follow-up». Journal of Young and Adolescence, 8, 453-472.

JOHN, R. S.; MEDNICK, S. A., SCHULSINGER, F. (1982). «Teacher reports as a predictor of schizophrenia and borderline schizophrenia: A Bayesian decision analysis». Journal of $A b$ normal Psychology, 6, 399-413.

KAGAN, J., MOSS, H. A. (1962). Birth to maturity; a study in psychological development. New York: Wiley.

Kagan, J.; ReZnick, S. J., Snidman, N. (1987). «The physiology and psychology of behavioral inhibition in children». Child Development, $58,1459-1473$.

KOHLBERG, L.; LACROSSE, J., RICKS, D. (1972). «The predictability of adult mental health from childhood behavior». In B. B. Wolman (ed.), Manual of child psychopathology, 1217-1284. New York: McGraw-Hill.

LaFrÉnière, P. J., Provost, M. A. (May, 1988). Concurrent associations between parentchild relations and internalizing behavior in the preschool. Paper presented at The Fifth Biennial University of Waterloo Conference on Child Development.

LEDINGHAM, J. E. (1981). «Developmental patterns of aggressive and withdrawn behavior in childhood: A possible method for identifying preschizophrenics". Journal of Abnormal Child Psychology, 10, 363-372.

LONDERVILLE, S., MAIN, M. (1981). "Security of attachment, compliance, and maternal training methods in the second year of lifex. Development Psychology, 17, 289-299.

Masten, A. S.; MORISON, P., Pellegrini, D. (1985). «A revised class play method of peer assessment». Developmental Psychology, 21, 523-533. 
MEAD, G. H. (1934). Mind, self, and society. Chicago: University of Chicago Press.

MICHAEL, C. M.; MORRIS, D. P., SOROKER, E. (1957). «Follow-up studies of shy, withdrawn children II: Relative incidence of schizophrenia». American Journal of Orthopsychiatry, 27, 331-337.

MOLler, L. C., RUBIN, K. H. (1988). «A psychometric assessment of a two-factor solution for the Preschool Behavior Questionnaire in mid-childhood». Journal of Applied Developmental Psychology.

MORRIS, D. P.; SOROKER, E., BuRRUSS, G. (1954). «Follow-up studies of shy, withdrawn, children I: Evaluation of later adjustment". American Journal of Orthopsychiatry, 24, 743-754.

Moskowitz, D. S.; SCHwartzman, A. E., Ledingham, J. E. (1985). "Stability and change in aggression and withdrawal in middle chilhood and early adolescence». Journal of Abnormal Psychology, 94, 30-41.

OLwEUS, D. (1981). «Child-to-child violence: Bullying among school-boys». In N. Cantwell (ed.), Children and violence, pp. 97-131. Stockholm: Akademilitteratur.

- (1979). "Stability of aggressive reaction patterns in males: A review. Psychological Bulletin, 86, 852-875.

PARker, J. G., Asher, S. R. (1987). «Peer relations and later personal adjustment: Are lowaccepted children at risk?». Psychological Bulletin, 102, 357-389.

PIAGET, J. (1926). The language and thought of the child. Londres: Routlege and Kegan Paul.

QUAY, H. C., LAGRECA, A. M. (1986). "Disorders of anxiety, withdrawal, and dysphoria". In H. C. Quay and J. S. Werry (eds.), Psychopathological disorders of childhood, pp. 73-110. Nueva York: Wiley.

RoBINS, L. N. (1966). Deviant children grown up. Baltimore, MD: Williams y Wilkins.

- (1972). "Follow-up studies of behavior disorders in children". In H. C. Quay and J. S. Werry (eds.), Psychopathological disorders of childhood, pp. 415-450. Nueva York: Wiley.

RUBIN, K. H. (1982a). «Social and social-cognitive developmental characteristic of young isolate, normal and sociable children». In K. H. Rubin and H. S. Ross (eds.), Peer relationsbips and social skills in childhood. Nueva York: Springer-Verlag.

- (1982b). "Non-social play in preschoolers. Necessarily evil?». Child Development, 53, 651-657.

- (1985). «Socially withdrawn children: An "at-risk" population?». In B. Schneider, K. H. Rubin and J. Ledingham (eds.), Peer relationships and social skills in childhod: Issues in assessment and training. Nueva York: Springer-Verlag.

RUBIN, K. H., BORWICK, D. (1984). "The communication skills of children who vary with regard to sociability». In H. Sypher and J. Applegate (eds.), Social cognition and communication. Hillsdale, New Jersey: Erlbaum.

RuBIN, K. H.; BREAM, L., ROSE-KRASNOR, L. (in press). «Social problem solving and aggression in childhood». In D. J. Pepler and K. H. Rubin (eds.), The development and treatment of chilhood aggression. Hillsdale, $\mathrm{NJ}$ : Erlbaum.

RuBin, K. H., CoHEN, J. S. (1986). «The Revised Class Play: Correlates of peer assessed social behavior in middle childhood». In R. J. Prinz (eds.), Advances in Behavioral Assessment of Children and Families, Vol. 2, pp. 179-206. Greenwich, Conn.: JAI Press.

RuBIN, K. H., DANIELS-BEIRNESS, T. (1983). "Concurrent and predictive correlates of sociometric status in Kindergarten and Grade 1 children». Merrill-Palmer Quarterly, 29, 337-351.

Rubin, K. H.; Daniels-Beirness, T., Bream, L. (1984). "Social isolation and social problem solving: A longitudinal study. Journal of Consulting and Clinical Psychology, 52, 17-25.

RuBin, K. H., HYMEL, S. (april, 1987). Predicting depression in childhood: A longitudinal investigation. Presented at the Biennial Meeting of the Society for Research in Child Development, Baltimore, Maryland.

Rubin, K. H.; Hymel, S.;, LeMARE, L. J., ROwDEN, L. (1989). «Children experiencing social difficulties: Sociometric neglect reconsidered». Canadian Journal of Behavioural Science, $21,94-111$.

RubiN, K. H.; Hymel, S., Mills, R. S. L. (1989). «Sociability and social withdrawal in childhood: Stability and outcomes». Journal of Personality, 57, 237-255.

Rubin, K. H., Hymel, S., Mills, R. S. L., Rose-Krasnor, L. (in press). "Conceptualizing different developmental pathways to and from social isolation in childhood». In D. Cicchetti (ed.), Rochester Symposium on Developmental Psychopathology, Vol. 2. Cambridge: Cambridge University Press.

RUBIN, K. H., KRASNOR, L. R. (1986). "Social cognitive and social behavior perspective on problem-solvingm. In M. Perlmutter (ed.), Minnesota Symposia on Child Psychology, Vol. 18. Hillsdale, N.J: Erlbaum.

Rubin, K. H., Lollis, S. (1988). "Origins and consequences of social withdrawal». In J. Belsky (ed.), Clinical implications of infant attachment, pp. 219-252. Hillsdale, N.J.: Erlbaum.

Rubin, K. H., Mills, R. S. L. (1988). «The many faces of social isolation in childhood». Journal of Consulting and Clinical Psychology, 56, 916-924. 
Rubin, K. H.; Moller, L. C., EMPTAGe, A. (1987). *The Preschool Behavior Questionnaire: A useful index of behavior problems in elementary school-age children? $\$$. Canadian Journal of Bebavioural Sciences, 19, 86-100.

SROUFE, L. A. (1983). *Infant-caregiver/attachment and patterns of adaptation in preschool: Roots of maladaption and competencew. In M. Perlmutter (ed.), Minnesota symposia on child psychology, Vol. 16. Hillsdale, N.J.: Erlbaum.

Sullivan, H.S. (1953). The interpersonal theory of psychiatry. New York: Norton, 1321-1334.

TROY, M., SROUFE, L. A. (1987). «Victimization among preschoolers: Role of attachment relationship history». Journal of the American Academy of Child and Adolescent Pychiatry, $26,166-172$.

YOUNGER, A. J., BOYKo, K. A. (in press). «Aggression and withdrawal as social schemas underlying children's peer perceptionsw. Child Development.

Younger, A. J., SCHwARTZMAN, A. E. LeDINGHAM, J. (1986). "Age-related differences in children's perceptions of social deviance: Changes in behavior or perspective?». Developmental Psychology, 22, 531-542.

\section{Resumen Extenso}

En este artículo se analizan los factores asociados con el retraimiento social en la infancia. Nuestra investigación parte de una creciente cantidad de datos que sugiere que la interacción con los compañeros es el foro en el que se desarrollan las habilidades sociales. En este sentido, los niños que no se relacionan con sus compañeros, están privados de la oportunidad de interactuar con los demás y corren el riesgo de presentar ciertas dificultades emocionales en su desarrollo.

Las dos áreas que generalmente se han admitido como indicativas de dificultades en las relaciones con los compañeros han sido el retraimiento social y la agresión. Mientras que la agresión ha sido objeto de numerosas investigaciones, el retraimiento social no se ha estudiado tan exhaustivamente. ¿Dónde se sitúan los orígenes de estas dos áreas de conflictividad? Rubin, Hymel, Mills y Rose-Krasnor (próxima publicación) han mantenido que las raíces del aislamiento y del rechazo de los compañeros evolucionan siguiendo dos trayectorias diferenciales. Describimos brevemente estos dos modelos propuestos para explicar los orígenes evolutivos del aislamiento social durante la infancia.

El resto del artículo se centra en la identificación, correlaciones y consecuencias del retraimiento social en la infancia. Los datos que presentamos pertenecen al Proyecto Longitudinal Waterloo, que comenzó en 1980 y que aún sigue en marcha. El objetivo principal de este Proyecto era estudiar la evolución de los niños con dificultades de relación con sus compañeros. Hemos realizado el seguimiento de una muestra desde la escuela infantil, la escuela primaria y esperamos continuar hasta que los niños, hoy adolescentes, terminen la enseñanza secundaria.

Identificamos el retraimiento social de los sujetos de nuestro estudio de dos modos. En el primero identificamos a los niños según el comportamiento observado en el juego (Rubin, 1982a). El 14,44\% de los niños observados por primera vez en la escuela infantil fueron identificados como aislados sociales. $2 / 3$ de estos niños mantenían este mismo status en el 2. ${ }^{\circ}$ curso de primaria.

En el segundo procedimiento se emplearon las designaciones de los compañeros. En concreto, adoptamos el Revised Class Play (Masten, Mo- 
rison y Pelligrini, 1985) para evaluar las percepciones de sociabilidad, liderazgo, agresión-trastorno y sensibilidad-aislamiento manifestadas por los compañeros. Nos interesaron de manera especial cuatro items del factor sensibilidad-aislamiento. Estos cuatro items reflejan el retraimiento pasivoansioso o niños que están aislados de pero no por el propio grupo de compañeros. Mediante estos procedimientos nominativos, se identificaron como socialmente retraídos el $18,18 \%, 22,22 \%$ y $23,37 \%$ de los niños pertenecientes a los cursos de $2 .^{\circ}, 4 .^{\circ}$ y $5 .^{\circ}$ de primaria respectivamente. Además, los datos longitudinales revelaron que el $69,23 \%$ de los niños de $4 .^{\circ}$ y el $54,54 \%$ de los niños de $5 .^{\circ}$ estaban aislados en $2 .^{\circ}$ Estos resultados junto con los obtenidos en las observaciones nos llevaron a concluir que el retraimiento social se mantiene relativamente estable durante los primeros años de escolarización.

Dado que el retraimiento social muestra una tendencia a persistir durante estos primeros años, examinamos las correlaciones asociadas con el aislamiento. Encontramos que los niños retraídos de cuatro y cinco años juegan de un modo mucho menos maduro desde un punto de vista cognitivo que sus colegas más sociales y tienden a hacer menor número de demandas a sus compañeros de juego. También manifiestan una mayor tendencia a solicitar la intervención de los adultos cuando deben afrontar dificultades interpersonales. A los siete años aproximadamente, los niños retraídos son calificados como pasivos y temerosos por sus compañeros. Además, a esta edad el retraimiento se correlaciona con un bajo concepto de autoestima. A los diez y once años, las dificultades internas de estos niños son más acusadas. El retraimiento se asocia con la autopercepción negativa de la competencia personal, la soledad y la depresión. Por último, las correlaciones predictivas revelaron que los niños que mostraron la conducta de juego más pasiva y retraída en la escuela infantil eran los más proclives a sufrir soledad y depresión en $4 .^{\circ}$ y $5 .^{\circ}$ de primaria respectivamente. Asimismo estos sujetos tenían un bajo concepto de sí mismos.

Este conjunto de datos nos ha llevado a creer que el retraimiento social en la infancia puede ser un síntoma de futuras dificultades. Nosotros mantenemos que el aislamiento infantil puede perdurar y tener consecuencias negativas en el bienestar de los sujetos. En la actualidad, seguimos investigando las consecuencias que pueden derivarse del retraimiento social durante la primera infancia. 